\title{
Universiteit
}

Leiden

The Netherlands

\section{Light chain skewing in autoantibodies and B-cell receptors of the citrullinated antigen-binding $B-c e l l$ response in rheumatoid arthritis}

Slot, L.M.; Vergroesen, R.D.; Kerkman, P.F.; Staudinger, E.; Reijm, S.; Dooren, H.J. van; ... ; Scherer, H.U.

\section{Citation}

Slot, L. M., Vergroesen, R. D., Kerkman, P. F., Staudinger, E., Reijm, S., Dooren, H. J. van, ... Scherer, H. U. (2021). Light chain skewing in autoantibodies and B-cell receptors of the citrullinated antigen-binding B-cell response in rheumatoid arthritis. Plos One, 16(3). doi:10.1371/journal.pone.0247847

Version: $\quad$ Publisher's Version

License: $\quad$ Creative Commons CC BY 4.0 license

Downloaded from: https://hdl.handle.net/1887/3196201

Note: To cite this publication please use the final published version (if applicable). 


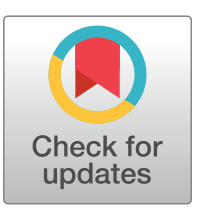

\section{G openaccess}

Citation: Slot LM, Vergroesen RD, Kerkman PF, Staudinger E, Reijm S, van Dooren HJ, et al. (2021) Light chain skewing in autoantibodies and B-cell receptors of the citrullinated antigen-binding B-cell response in rheumatoid arthritis. PLOS ONE 16(3): e0247847. https://doi.org/10.1371/journal. pone.0247847

Editor: Salvatore V. Pizzo, Duke University School of Medicine, UNITED STATES

Received: August 24, 2020

Accepted: February 13, 2021

Published: March 30, 2021

Copyright: ( $\odot 2021$ Slot et al. This is an open access article distributed under the terms of the Creative Commons Attribution License, which permits unrestricted use, distribution, and reproduction in any medium, provided the original author and source are credited.

Data Availability Statement: All relevant data are present within the manuscript and its Supporting Information files.

Funding: This study was supported by grants from the Dutch Arthritis Foundation (project no. 12-2403, REM Toes; no. 15-2-402, HU Scherer and no. 18-1-205, HU Scherer), the Netherlands Organization for Scientific Research (NWO; project no. 91214031, REM Toes), a ZonMW clinical fellowship (project no. 90714509, HU Scherer),
RESEARCH ARTICLE

\section{Light chain skewing in autoantibodies and B- cell receptors of the citrullinated antigen- binding B-cell response in rheumatoid arthritis}

\author{
Linda M. Slot ${ }^{\circledR}$, Rochelle D. Vergroesen ${ }^{\circledR}$, Priscilla F. Kerkman ${ }^{\star}$, Ellen Staudinger, \\ Sanne Reijm, Hugo J. van Dooren, Ellen I. H. van der Voort, Tom W. J. Huizinga, René E. \\ M. Toes, Hans U. Scherer $\mathbb{B}^{*}$ \\ Department of Rheumatology, Leiden University Medical Center, Leiden, The Netherlands \\ ( ) These authors contributed equally to this work. \\ a Current address: Department of Medical Microbiology, University Medical Center Utrecht, Utrecht, The \\ Netherlands \\ * h.u.scherer@lumc.nl
}

\section{Abstract}

Rheumatoid arthritis (RA) is a chronic autoimmune disease affecting $1 \%$ of the world population. $R A$ is associated with the presence of autoantibodies, of which anti-citrullinated protein antibodies (ACPA) are most prominent. ACPA are produced by citrullinated antigenbinding $B$ cells that have presumably survived tolerance checkpoints. So far, it is unclear how and when such autoreactive $B$ cells emerge. Light chain (LC) rearrangement and mutation rates can be informative with regard to selection steps during $B$-cell development. Therefore, we studied LC characteristics of ACPA-expressing B cells and secreted ACPA with the aim to better understand the development of this disease-specific, autoreactive $B$ cell response. Paired ACPA-IgG and ACPA-depleted IgG were isolated from serum $(n=87)$ and synovial fluid (SF, $n=21$ ) of patients with established RA. We determined the LC composition for each fraction by ELISA using kappa( $\operatorname{lgk})$ - and $\operatorname{lambda}(\lg \lambda) \mathrm{LC}$-specific antibodies. Cellular LC expression was determined using flow cytometry. In addition, we used a Bcell receptor (BCR)-specific PCR to obtain LC variable region sequences of citrullinated antigen- and tetanus toxoid (TT)-binding B cells. In serum, we observed an increased frequency of lambda LC in ACPA-IgG (1.64:1) compared to control $\lg \mathrm{G}(2.03: 1)$ and to the $\mathrm{k} / \mathrm{\lambda}$ ratio reported for healthy individuals $(2: 1)$. A similar trend towards higher frequencies of lambda LCs was observed for ACPA-IgG in SF (1.84:1). Additionally, the percentage of Ig $\lambda$-expressing $B$ cells was higher for citrullinated antigen-binding $B$ cells (51\%) compared to TT-specific $(43 \%)$ and total $\mathrm{CD} 19^{+} \mathrm{CD} 20^{+} \mathrm{B}$ cells $(36 \%)$. Moreover, an increased $\lg \lambda$ percentage was observed in BCR-sequences derived from ACPA-expressing (49\%) compared to TT-specific $B$ cells (34\%). Taken together, we report an enhanced frequency of lambda LCs in the secreted ACPA-IgG repertoire and, on the cellular level, in BCR sequences of ACPAexpressing $B$ cells compared to control. This skewing in the autoreactive B-cell repertoire could reflect a process of active selection. 
ZonMW VENI grant (no. 91617107, HU Scherer), ZonMW OffRoad grant (no. 451001012, HU Scherer), the IMI-funded consortium projects BeTheCure (contract no. 115142-2, REM Toes) and RTCure (contract no. 777357, REM Toes) and has been funded as part of the Target-to-B! consortium by 'Samenwerkende Gezondheidsfondsen' (SGF) consisting of 20 health funds including KWF Kankerbestrijding, ReumaNederland, Topsector Life Sciences \& Health (Health Holland) and the Business Life (LSHM18055-SGF). R.E.M.T. is the recipient of an European Research Council (ERC) Advanced grant (AdG2019-884796). The funders had no role in study design, data collection and analysis, decision to publish, or preparation of the manuscript.

Competing interests: The authors have declared that no competing interests exist.

\section{Introduction}

The majority of rheumatoid arthritis (RA) patients harbor autoantibodies that recognize citrullinated proteins (commonly termed anti-citrullinated protein antibodies, ACPA). A hallmark of ACPA is their specificity for RA. ACPA can be detected before the onset of disease and are valuable biomarkers in clinical practice [1-3]. Interestingly, ACPA levels in serum of RA patients correlate with the frequency of citrullinated antigen-binding (ACPA-expressing) B cells in peripheral blood [4] and can reach levels similar to peak levels of protective antibody responses against recall antigens such as tetanus toxoid (TT) $[1,2,5]$. However, the avidity of ACPA is remarkably low compared to other antibody responses (e.g. against TT) despite a much higher somatic hypermutation rate [1,6-8]. Moreover, ACPA-IgG were found to be highly glycosylated in the variable domain and to be highly cross-reactive with other post-translational protein modifications [9-11]. This is intriguing, as it suggests that ACPA-expressing B cells deviate from the 'conventional' mechanisms of positive and negative selection and affinity maturation that are thought to govern the generation of high avidity, non-autoreactive clones, such as those observed against recall antigens [12]. Conventionally, such selection processes occur at various stages of B-cell development and lead to modifications of the B-cell receptor (BCR) aimed at minimizing autoreactivity, while maintaining a broad repertoire capable of mounting a protective immune response. Such modifications can affect both chains of the BCR, nevertheless, most studies on autoreactivity focus on the heavy chain. The alterations to the BCR can occur centrally during B-cell development in the bone marrow and in germinal centers (GC) or GClike structures in the periphery. Understanding these processes in the context of human autoreactive $B$ cells may be crucial to comprehend how ACPA-expressing B cells escape tolerance checkpoints and at what stage of B-cell development tolerance is breached.

BCR light chains (LCs) are initially generated in the bone marrow after successful rearrangement and expression of the heavy chain (HC). LC rearrangement starts on the immunoglobulin kappa (Igא) locus, but when resulting in an unproductive rearrangement, it will lead to negative selection of the $\mathrm{B}$ cell in the bone marrow before entering the periphery. Likewise, LC rearrangement can result in an autoreactive BCR, which can also lead to negative selection by either apoptosis or anergy induction. Alternatively, B cells can rearrange the LC of the autoreactive BCR (receptor editing). The new LC can consist of V-genes positioned towards the 5' end and/or J-genes positioned towards the 3' end of the Igא locus, can consist of V-genes on the second Igא allele or of $\mathrm{V}$-genes on one of the immunoglobulin lambda (Ig $\lambda$ ) loci $[13,14]$. The characteristics of LCs are interesting in the context of selection, as the use of kappa or lambda $\mathrm{V}$-genes and the LC mutation rate can be indicative of consecutive rearrangements during B-cell development. In addition, $\mathrm{V}$-gene restriction may indicate structural requirements for antigen recognition [15-18].

Overall, the aforementioned processes result in an average $\kappa / \lambda$ LC ratio of 2:1 for antibodies in serum of healthy individuals $[19,20]$. Notably, the probability of a B cell expressing Ig $\lambda$ increases with each round of BCR editing. Thus, a decreased $\kappa / \lambda \mathrm{LC}$ ratio in a particular BCR repertoire can indicate multiple rounds of BCR editing in the bone marrow to avoid the expression of autoreactive BCRs, thereby allowing $B$ cells to escape negative selection.

Next to these central mechanisms, B cells can undergo secondary BCR rearrangement in the periphery (receptor revision), as has been reported in GC(-like) structures in the synovium of RA patients [21-23], in circulating human peripheral blood B lymphocytes [24], in leukaemia patients [25] and in murine B-cell lines and in vivo mouse models [26-28]. Similar to receptor editing, multiple rounds of receptor revision can lead to a decrease in the $\kappa / \lambda \mathrm{LC}$ ratio, presumably reflecting an attempt to escape from negative selection against autoreactivity. 
Together, these considerations indicate that LC rearrangements in a given BCR repertoire can reflect selective pressure during (autoreactive) B-cell development. This makes such BCR rearrangements valuable sources of information in an effort to understand autoreactive B-cell responses. Here, we used multiple methods to investigate the $\kappa / \lambda \mathrm{LC}$ ratio in the ACPA-expressing B-cell repertoire to obtain insight in the BCR composition of autoreactive B cells that escaped tolerance checkpoints. Our results demonstrate an increased frequency of lambda LCs in ACPA-IgG isolated from serum and synovial fluid, an increased percentage of citrullinated antigen-binding $B$ cells expressing the lambda LC as measured by flow cytometry and an increase in lambda LCs in BCR sequences derived from single cell- and pool-sorted citrullinated antigen-binding B cells.

\section{Methods}

\section{Patients}

Peripheral blood, serum and synovial fluid (SF) samples were obtained from patients diagnosed with ACPA-positive RA visiting the outpatient clinic of the Department of Rheumatology at Leiden University Medical Center (LUMC), Leiden, The Netherlands. Patients fulfilled the 2010 classification criteria for RA [29] at the time of diagnosis and gave written informed consent for sample acquisition. Patients treated with biological or B-cell depleting agents were excluded. This study was approved by the Institutional Review Board of the Leiden University Medical Center (approval number P17.151).

\section{ACPA purification using CCP2-coated beads}

ACPA were purified from serum and SF of RA patients by antigen affinity chromatography using $2^{\text {nd }}$ generation cyclic citrullinated peptide (CCP2)-coated beads, as previously described [30]. In short, biotinylated CCP2 $(0.5 \mathrm{mg})$ was added to $5 \mathrm{~mL}$ of Pierce NeutrAvidin Plus UltraLink slurry resin (Thermo Scientific). After washing, beads were loaded into a 96-well filter plate. Serum or SF samples (1:5 diluted) were added and incubated for 2 hours while shaking. ACPA bound to the resin were eluted by washing with $0.1 \mathrm{M}$ formic acid, followed by direct neutralization with $2 \mathrm{M}$ Tris buffer. The flow-through was obtained by centrifugation and one washing step, resulting in serum or SF ACPA-deleted control samples. CCP2 ELISAs were performed to validate ACPA purification in isolated ACPA and ACPA-depleted control samples. Samples with incomplete isolation/depletion were excluded from the analysis.

\section{ELISA of secreted antibodies in serum, synovial fluid and culture supernatants}

The presence of light chains (LC) in ACPA-IgG was assessed by incubation of isolated ACPA or ACPA-depleted serum ( $\mathrm{n}=87$ patients) and SF ( $\mathrm{n}=21$ patients) on ELISA plates coated with mouse anti-human immunoglobulin lambda LC (Ig $\lambda$; clone JDC-12, BD Pharmingen) or mouse anti-human immunoglobulin kappa LC (Igא; clone G20-193, BD Pharmingen) monoclonal antibodies. ACPA bound by the respective anti-LC antibodies were detected with polyclonal rabbit anti-human IgG-HRP (DAKO). Human reference serum (Bethyl Laboratories) was used as standard in all ELISA experiments and for data normalization.

ACPA-Ig levels in citrullinated antigen-binding B-cell cultures were based on reactivity towards the CCP2-peptide. Biotinylated CCP2-peptides were coupled to streptavidin-coated ELISA plates, followed by incubation with 1:2 diluted supernatant from cultures. ACPA-Ig levels were detected with secondary antibodies for IgG (rabbit anti-human IgG-HRP, DAKO), IgM (goat anti-human IgM-HRP, Millipore) or IgA (goat anti-human IgA-HRP, Invitrogen) to identify Ig-isotypes. The presence of tetanus toxoid (TT)-specific antibodies in supernatants 
of TT-specific B-cell cultures was determined using TT-coated (Staten Serum Institute) plates. Detection of TT-specific antibodies was identical to Ig-detection of ACPA.

\section{Flow cytometry}

Streptavidin tetramers were used to identify ACPA-expressing B cells as previously described [4]. Peripheral blood mononuclear cells (PBMCs) were isolated from $40 \mathrm{ml}$ of peripheral blood by Ficoll-Paque gradient centrifugation and stained with Fixable Violet (405nm) Dead Cell Stain kit (Thermofisher), CD3 Pacific Blue (clone UCHT1, BD Pharmingen), CD14 Pacific Blue (clone M5E2, BD Pharmingen), CD19 APC-Cy7 (clone SJ25C1, BD Pharmingen), CD20 AlexaFluor 700 (clone 2H7, BD Pharmingen) and CD27 PE-Cy7 (clone M-T271, BD Pharmingen). Citrullinated antigen-binding $B$ cells were identified by a double positive staining using two CCP2-containing tetramers (APC- and BV605-labelled) and negative staining for the arginine control variant (PE-labelled). Similarly, $\mathrm{CD} 19^{+} \mathrm{CD} 20^{+}$double positive $\mathrm{B}$ cells were considered TT-specific if they stained double positive for TT-APC and TT-PE.

Furthermore, in flow cytometry experiments used to determine Igא and Ig $\lambda$ frequencies on the cellular level, cells were additionally stained with Igא VioGreen (clone IS1124D5, Miltenyi Biotec) and Ig $\lambda$ FITC (clone IS724C7, Miltenyi Biotec). In-depth gating strategy for determination of Igא and Ig $\lambda$ expression can be found in S1 Fig.

For FACS-sort experiments to isolate citrullinated antigen- and TT-binding B cells for single cell culture and sequencing, the panel was extended with IgG BV510 (BD Horizon, clone G18-145) and IgD FITC (clone IA6-2, BD Pharmingen). ACPA-expressing B cells were sorted on a BD FACSAriaII/III flow cytometer as pools of ten cells/well for direct lysis $\left(\mathrm{CD} 19^{+}\right)$or as one cell/well for culture $\left(\mathrm{CD} 19^{+} \mathrm{CD} 20^{+}\right)$, TT-specific B cells were only sorted as one cell/well for culture $\left(\mathrm{CD} 19^{+} \mathrm{CD} 20^{+}\right)$.

\section{Single cell cultures}

Single cell-sorted citrullinated antigen-binding $\mathrm{CD}_{1} 9^{+} \mathrm{CD} 20^{+} \mathrm{B}$ cells (obtained from $\mathrm{n}=19$ patients) and TT-binding B cells (obtained from $\mathrm{n}=4$ of 19 patients) were cultured in 96-wells flat bottom plates on a layer of irradiated mouse fibroblasts transfected with human CD40 ligand (CD40L L-cells, 70Gy irradiated, $1 \times 10^{4}$ cells/well) in Iscove's Modified Dulbecco's Medium containing $8 \%$ heat-inactivated fetal calf serum (FCS), $100 \mathrm{U} / \mathrm{mL}$ penicillin/streptomycin and $1.82 \mathrm{mM}$ GlutaMax for 10-13 days. Additionally, this culture medium contained $1 \mathrm{ng} / \mathrm{ml}$ IL-1 (R\&D Systems), 500ng/ml R848 (Invivogen), 50ng/ml IL-21 (Gibco), 0.3ng/ml

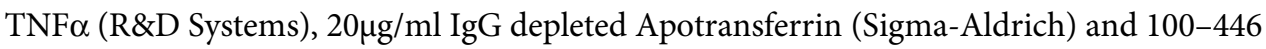
$\mathrm{nM} \beta$-mercaptoethanol (Merck) as used previously [31].

\section{mRNA isolation and cDNA synthesis}

Direct mRNA lysis was performed on pools of $10 \mathrm{CD} 19^{+}$citrullinated antigen-binding $\mathrm{B}$ cells with a mixture of $0.2 \%$ Triton X-100 (Sigma) in $\mathrm{ddH}_{2} \mathrm{O}$, RNase inhibitor ( $25 \mathrm{U}$, TaKaRa), OligodT30VN (10 pmol, S1 Table, IDT) and dNTPs (10 nmol, ThermoFisher) per pool. mRNA from single cell cultures was isolated using TRIzol reagent following the manufacturer's protocol (ThermoFisher). $300 \mu \mathrm{L}$ of TRIzol was used for cell lysis and mRNA was precipitated overnight with isopropanol. Subsequently, Oligo-dT30VN (10 pmol) and dNTPs $(10 \mathrm{nmol})$ were added. cDNA from both pool-isolated and single cell-isolated mRNA was synthesized using the following method: mRNA was incubated for $3 \mathrm{~min}$. at $72^{\circ} \mathrm{C}$. Subsequently, 5x first-strand buffer (TaKaRa), Betaine BioUltra (10 $\mu \mathrm{mol}$, Sigma-Aldrich), DTT (10 nmol, TaKaRa), RNase inhibitor (10 U), SMARTScribe reverse transcriptase (50 U, TaKaRa), Template-Switching Oligo (TSO, 10 pmol, S1 Table, Exiqon) and RNAse-free water was added per sample. Samples were incubated for 90 
min. at $42^{\circ} \mathrm{C}$, followed by 10 cycles of $2 \mathrm{~min}$. at $50^{\circ} \mathrm{C}$ and $2 \mathrm{~min}$. at $42^{\circ} \mathrm{C}$. cDNA synthesis was finalized by incubation for $15 \mathrm{~min}$. at $72^{\circ} \mathrm{C}$. cDNA of pool-sorted samples was pre-amplified by adding Phusion Flash High-Fidelity PCR Master Mix (1x, ThermoFisher), RNAse-free $\mathrm{H}_{2} \mathrm{O}$ and ISPCR (2.5 pmol, S1 Table, IDT) for a second PCR reaction. Samples were incubated for $2 \mathrm{~min}$. at $98^{\circ} \mathrm{C}$, followed by 23 cycles of $3 \mathrm{sec}$. at $98^{\circ} \mathrm{C}, 15 \mathrm{sec}$. at $67^{\circ} \mathrm{C}$ and $5 \mathrm{~min}$. at $72^{\circ} \mathrm{C}$, followed by a final extension for $5 \mathrm{~min}$. at $72^{\circ} \mathrm{C}$. Pre-amplified pool-sorted cDNA was purified using Agencourt AMPureXP magnetic beads (Beckman Coulter) following the manufacturer's protocol, with exception of a 5:4 ratio of cDNA:beads and elution in $15 \mu \mathrm{L}$ nuclease-free $\mathrm{H}_{2} \mathrm{O}$.

\section{ARTISAN PCR}

Immunoglobulin PCR products were amplified using an adapted protocol for low cDNA amount based on the Anchoring Reverse Transcription of Immunoglobulin Sequences and Amplification by Nested (ARTISAN) PCR [32]. $2 \mu \mathrm{L}$ of cDNA was added to a combination of Phusion Flash High-Fidelity PCR Master Mix (0.5x), nuclease-free $\mathrm{H}_{2} \mathrm{O}$, SA forward primer (5 pmol, SA.pcr)

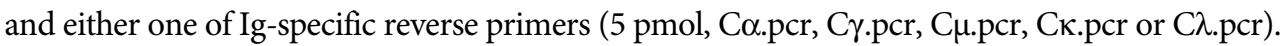
Mixtures were incubated for $2 \mathrm{~min}$. at $98^{\circ} \mathrm{C}$, followed by 40 cycles of $1 \mathrm{sec}$. at $98^{\circ} \mathrm{C}, 15 \mathrm{sec}$. at $69^{\circ} \mathrm{C}$ and $15 \mathrm{sec}$. at $72^{\circ} \mathrm{C}$, and final extension for $1 \mathrm{~min}$. at $72^{\circ} \mathrm{C}$. Subsequently, each pool-sorted ARTISAN sample was barcoded by adding a mix of Phusion Flash High-Fidelity PCR Master Mix (1x), nuclease-free $\mathrm{H}_{2} \mathrm{O}$, one of the SA forward barcode family primers (5 pmol, SA.bc) and one of the Ig-specific reverse barcode family primers ( $5 \mathrm{pmol}, \mathrm{C} \alpha . b c, C \gamma . b c, C \mu . b c, C \kappa . b c$ or $\mathrm{C} \lambda . \mathrm{bc})$. Mixtures were incubated for $2 \mathrm{~min}$. at $98^{\circ} \mathrm{C}$, followed by 10 cycles of $1 \mathrm{sec}$. at $98^{\circ} \mathrm{C}, 15 \mathrm{sec}$. at $65^{\circ} \mathrm{C}$ and $15 \mathrm{sec}$. at $72^{\circ} \mathrm{C}$, and final extension for $1 \mathrm{~min}$. at $72^{\circ} \mathrm{C}$. See $\mathrm{S} 1$ Table for sequences of ARTISAN and barcoding primers. All primers were purchased from IDT.

\section{BCR sequencing}

ARTISAN products from single-sorted cells were used for Sanger sequencing on the Applied Biosystems 96-capillary (ABI3730xl) system. Barcoded products from pool-sorted cells were pooled in 1:1 ratios, purified and sequenced on the PacBio RSII system.

\section{Data analyses}

Barcodes corresponding to different pools and donors were separated with Geneious 9.1.8. Both single- and pool-sorted sequences were analyzed with IMGT-(high)Vquest [33], ARGalaxy [34] and Microsoft Access to define B cell clones as unique productive sequences based on identical V-gene+J-gene+CDR3(AA) (S2 Table). Clones were identified to avoid bias caused by clonal expansion or differences in BCR mRNA expression in resting versus activated $\mathrm{B}$ cells. LC sequences obtained from single-sorted ACPA-expressing B cells were selected for all IgH isotypes ( $\operatorname{Ig}_{\text {all }}$ ) or the IgG isotype only. Sequencing data from pool-sorted ACPA-expressing B cells contained LC paired with HC transcripts from IgG (83\%), IgA (11\%) and IgM (6\%) cells, but direct HC-LC pairing is not compatible with the PacBio sequencing method. Statistical analyses were performed using GraphPad prism 8.0. Correlations were assessed as parametric paired correlations, One-way ANOVA or Chi square tests and corrected with Holm-Bonferroni for multiple comparisons. $P$ Values $<0.05$ were considered significant.

\section{Results}

\section{Lambda LC in secreted ACPA-IgG isolated from serum and SF}

We first determined the frequency of lambda and kappa LCs of secreted ACPA-IgG in serum and synovial fluid. To this end, ACPA were isolated from serum of $87 \mathrm{RA}$ patients using 


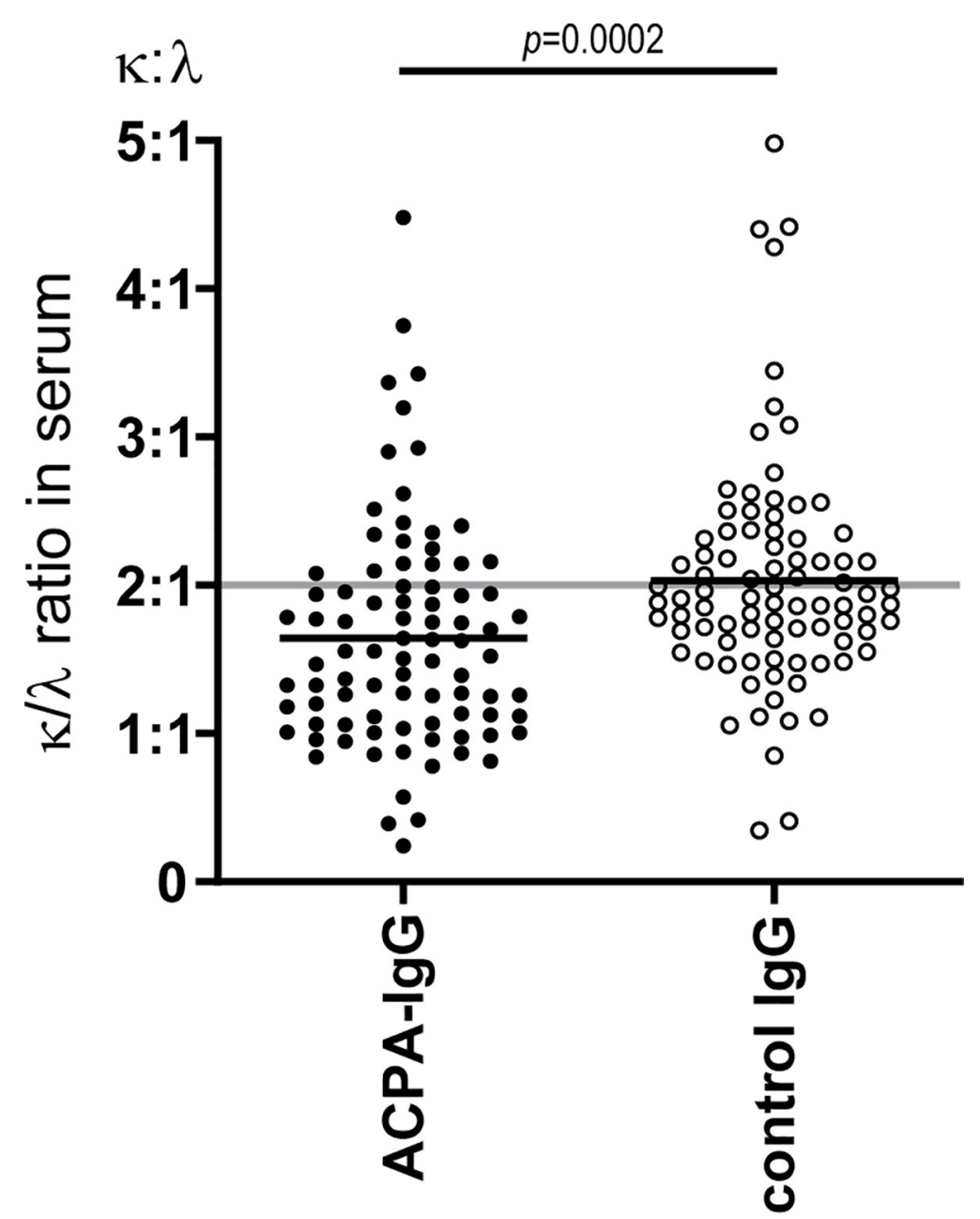

Fig 1. Frequency of lambda LC in ACPA-IgG and control IgG in serum of RA patients. $\kappa / \lambda$ ratios in paired ACPA-IgG and control IgG in serum of RA patients $(n=87)$ where the grey line depicts the $\kappa / \lambda$ ratio of $2: 1(67 \%-33 \%)$ in healthy individuals as reported in literature. Data were assessed as parametric paired samples in student's $t$-test.

https://doi.org/10.1371/journal.pone.0247847.g001

CCP2-coated beads, resulting in paired samples containing "ACPA-IgG" or "IgG depleted of ACPA" (control IgG) per patient. The average $\kappa / \lambda$ ratio in control IgG was equal to 2.03 (SD 0.77 , Fig 1$)$ as expected for normal human serum (2:1) [19,20]. In contrast, the frequency of lambda LC was significantly increased in ACPA-IgG (mean $\kappa / \lambda$ ratio 1.64 , SD $0.75 ; p=0.0002$, Fig 1; Table 1). Additionally, ACPA-IgG were isolated from SF of 21 patients to study if the higher frequency of lambda LC was also present in this compartment. Indeed, a similar trend was observed in SF, with ACPA-IgG containing relatively more lambda LC (mean $\kappa / \lambda$ ratio 1.84 , SD 0.82; Table 1 ) than control IgG (mean $\kappa / \lambda$ ratio 2.02 , SD 0.65 ; Table 1 ), although this difference did not reach statistical significance.

\section{Igא and Ig $\lambda$ expression on B cells}

Next, we investigated whether the increased lambda LC frequency present in secreted ACPA-IgG was related to antibody production by Ig $\lambda$-expressing plasma cells, or whether an overall increase in Ig $\lambda$ expression by citrullinated antigen-binding B cells could be detected. We studied the IgK and Ig $\lambda$ expression in citrullinated antigen-binding and control B cells (i.e. TT-specific B cells and total $\mathrm{CD} 19^{+} \mathrm{CD} 20^{+} \mathrm{B}$ cells) using flow cytometry (Fig $2 \mathrm{~A}$ ). 
Table 1. Summary of all $\kappa / \lambda$ LC ratios observed in ACPA-expressing, TT-specific and total IgG/total $\mathrm{CD} 19^{+} \mathrm{CD20}{ }^{+} \mathrm{B}$ cells as measured with ELISA, flow cytometry and BCR sequencing.

\begin{tabular}{|c|c|c|c|}
\hline & ACPA $\kappa / \lambda$ & TT $\kappa / \lambda$ & total $\kappa / \lambda$ \\
\hline Serum $(\operatorname{IgG})$ & 1.64:1 & - & $2.03: 1^{* * *}$ \\
\hline \multirow[t]{2}{*}{ SF (IgG) } & $1.84: 1$ & - & $2.02: 1$ \\
\hline & ACPA $\kappa / \lambda(\%)$ & $\mathrm{TT} \kappa / \lambda(\%)$ & total $\kappa / \lambda(\%)$ \\
\hline FACS $\left(\operatorname{Ig}_{\text {all }}\right)$ & 49:51 & $64: 36^{* * * *}$ & $57: 43^{* *}$ \\
\hline Single cell seq. (Igall cells) & $51: 49$ & $66: 34^{*}$ & - \\
\hline Single cell seq. (IgG cells) & $52: 48$ & $64: 36$ & - \\
\hline Single cell seq. (Igall clones) & $54: 46$ & $69: 31$ & - \\
\hline Single cell seq. (IgG clones) & $53: 47$ & $67: 33$ & - \\
\hline Pool seq. ( $\left.\operatorname{Ig}_{\text {all }}\right)$ & $63: 37$ & - & - \\
\hline
\end{tabular}

Statistical tests resulting in significant differences between ACPA and TT data or ACPA and total IgG/total $\mathrm{CD} 19^{+} \mathrm{CD} 20^{+} \mathrm{B}$ cells data are depicted with level of significance in the column of the group to which ACPA was compared.

IgG = immunoglobulin $\mathrm{G}$.

$\mathrm{Ig}_{\mathrm{all}}=$ all immunoglobulin isotypes $(\mathrm{IgA}, \operatorname{IgG}$ or $\operatorname{IgM})$.

$\mathrm{SF}=$ synovial fluid

FACS = flow cytometry.

seq $=$ sequencing.

scSeq $=$ single cell sequencing.

ACPA $=$ anti-citrullinated protein antibodies.

$\mathrm{TT}=$ tetanus toxoid.

total $=$ control; total IgG in ELISA or total $\mathrm{CD} 19^{+} \mathrm{CD} 20^{+} \mathrm{B}$ cells in FACS.

dash $(-)=$ not determined.

level of significance; $p \leq 0.05={ }^{*}, p \leq 0.01={ }^{* *}, p \leq 0.001={ }^{* * *}, p<0.0001={ }^{* * * *}$.

https://doi.org/10.1371/journal.pone.0247847.t001

The number of analyzed cells varied between donors: 9-181 (median 23) for citrullinated antigen-binding B cells, 13-199 (median 59) for TT-specific B cells and 182,980-1,962,822 (median 556,826) for total $\mathrm{CD} 19^{+} \mathrm{CD} 20^{+} \mathrm{B}$ cells. Seven out of nine donors showed a similar pattern with an enhanced Ig $\lambda$ frequency in citrullinated antigen-binding $B$ cells compared to total $\mathrm{CD} 19^{+} \mathrm{CD} 20^{+} \mathrm{B}$ cells. In six out of these seven donors, citrullinated antigen-binding $\mathrm{B}$ cells expressed Ig $\lambda$ more frequently than TT-specific control cells (Fig 2B; Table 1). Furthermore, when absolute numbers of $\mathrm{CD} 19^{+} \mathrm{CD} 20^{+}$, citrullinated antigen- and TT-binding cells of all 9 donors were pooled and analyzed for LC expression, a significant increase in Ig $\lambda$-positive $\mathrm{B}$ cells was observed for citrullinated antigen-binding $\mathrm{B}$ cells compared to total $\mathrm{CD} 19^{+} \mathrm{CD} 20^{+}$ B cells $(p=0.0024)$ and TT-specific B cells $(p<0.0001)$. TT-specific B cells showed a higher frequency of Igк compared to total $\mathrm{CD} 19^{+} \mathrm{CD} 20^{+}$cells (Fig $2 \mathrm{C}$ ). Additionally, $4.8 \%$ of citrullinated antigen-binding $B$ cells expressed double positive Igא/Ig $\lambda$ BCRs, (observed in four out of nine RA patients) compared to $1.5 \%$ of TT-specific B cells (observed in five out of nine RA patients) and $0.5 \%$ of total $\mathrm{CD} 19^{+} \mathrm{CD} 20^{+} \mathrm{B}$ cells (observed in all donors).

In summary, an enhanced frequency of Ig $\lambda$ in citrullinated antigen-binding $B$ cells was observed compared to total and TT-specific B cells from the same patients, although this was not the case for all donors.

\section{Frequency of Igא and Ig $\lambda$ in BCR sequences}

Next, we studied LC sequences obtained from citrullinated antigen- and TT-binding B cells to determine whether the increased Ig $\lambda$ expression observed with flow cytometry was due to the 
A
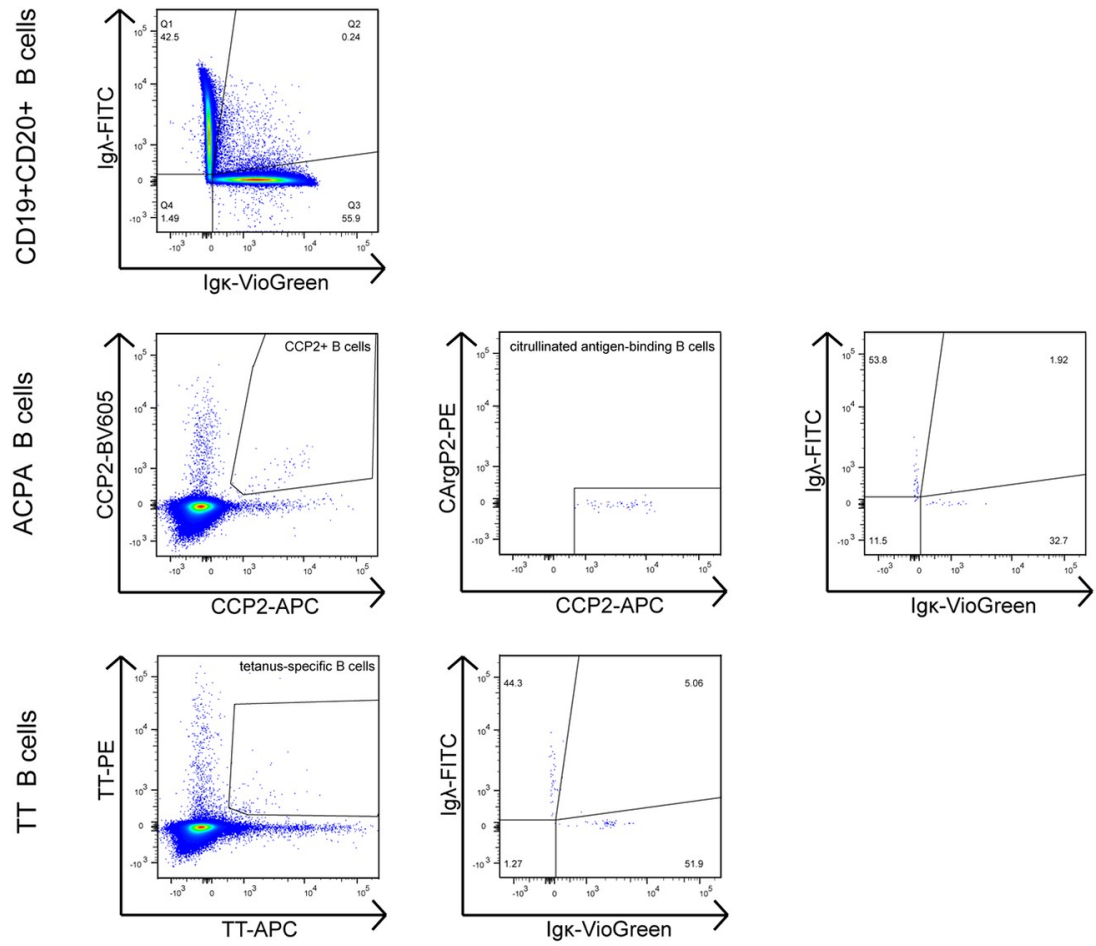

B
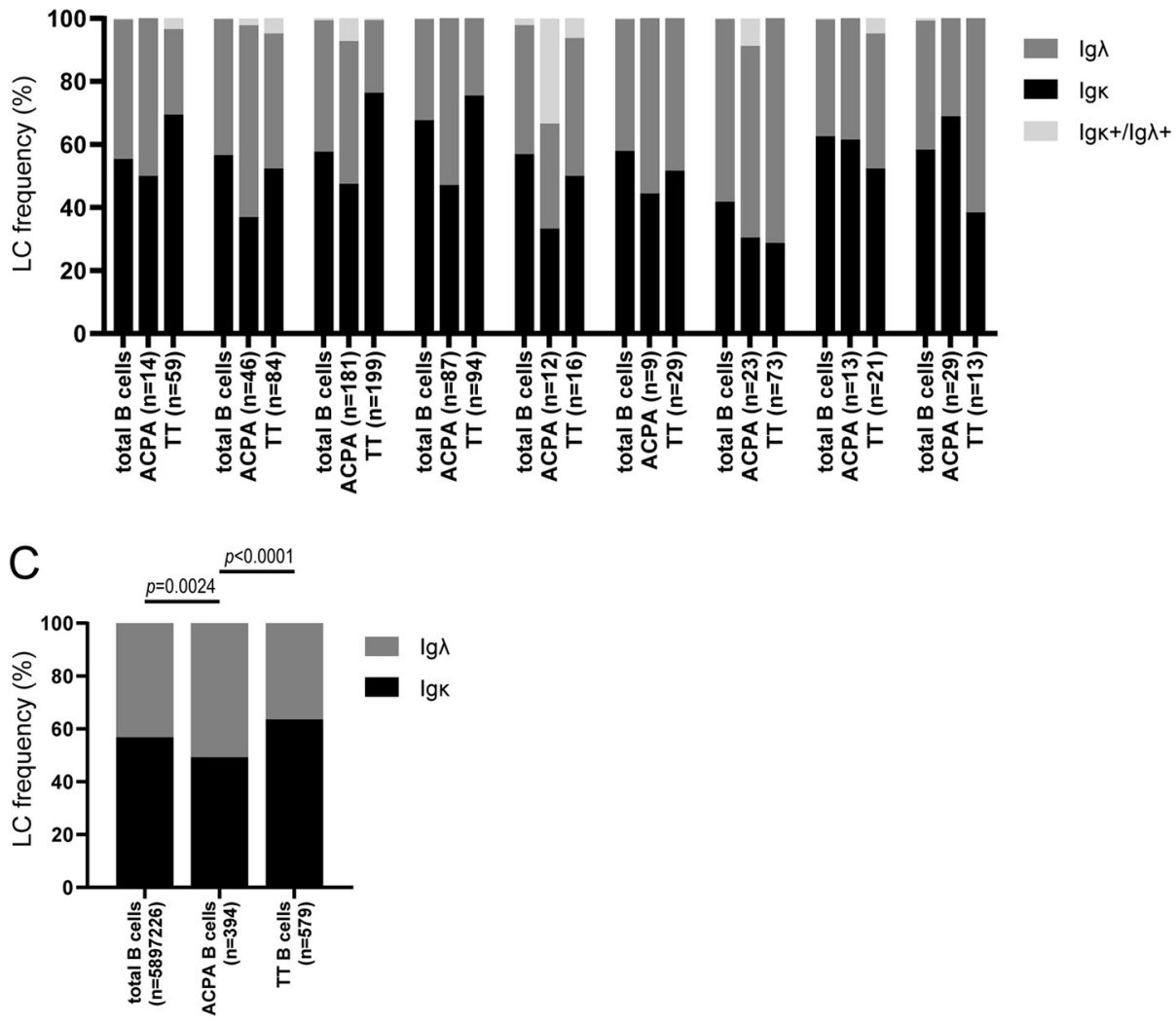
Fig 2. Igא and Ig $\lambda$ expression by total $\mathrm{CD}^{+} 9^{+} \mathrm{CD}^{+}{ }^{+}$, citrullinated antigen- and TT-binding $\mathrm{B}$ cells measured with flow cytometry. A) $\mathrm{CD} 19^{+} \mathrm{CD} 20^{+}$double positive B cells were gated as Igא- or Ig $\lambda$-expressing B cells based on isotype controls. Cells were defined as citrullinated antigen-binding B cells when cells were double positive for CCP2-APC and CCP2-BV605 tetramers, while negative for CArgP2-PE control. Cells were defined as TT-specific B cells when double positive for both TT-PE and TT-APC tetramers. B) LC expression by total $\mathrm{CD} 19^{+} \mathrm{CD} 20^{+} \mathrm{B}$ cells, citrullinated antigenbinding $B$ cells and TT-specific B cells in RA patients $(n=9)$. A low frequency of double negative $\left(\operatorname{IgK}{ }^{-} / \operatorname{Ig} \lambda^{-}\right)$cells were excluded from this analysis as their LC expression could not be determined with certainty. C) Frequency of LC expression based on the total number of cells expressing IgK or Ig $\lambda$ from data of 9 RA donors depicted in B. Double negative $\left(\operatorname{Ig} \kappa^{-} / \operatorname{Ig} \lambda^{-}\right)$and double positive $\left(\operatorname{Ig\kappa }{ }^{+} / \operatorname{Ig} \lambda^{+}\right)$cells were excluded from this analysis. Data were analyzed with the Chi square test and Holm-Bonferroni for multiple comparisons.

https://doi.org/10.1371/journal.pone.0247847.g002

expansion of individual Ig $\lambda$ expressing B-cell clones. To this end, citrullinated antigen-binding $\mathrm{CD} 19^{+} \mathrm{CD} 20^{+} \mathrm{B}$ cells from 19 patients were sorted one cell per well and expanded in vitro for $10-13$ days. In addition, TT-binding $\mathrm{CD} 19^{+} \mathrm{CD} 20^{+} \mathrm{B}$ cells from 4 of these 19 patients were sorted and cultured using the identical protocol. Antibodies in the supernatant of cultured cells were tested with ELISA to determine CCP2- or TT-reactivity. Subsequently, cell lysis, cDNA synthesis, specific BCR amplification and Sanger sequencing were performed. This resulted in LC sequences of 191 citrullinated antigen- and 59 TT-binding B cells ( Igall $\left._{\text {all }}\right)$, of which 153 and 59 were of the IgG isotype, respectively. In both Ig all- $^{-}$and IgG-(sub)datasets, ACPA-expressing B cells contained a higher frequency of $\operatorname{Ig} \lambda(49.2 \%$ and $48.4 \%$, respectively) compared to TT-specific B cells (33.9\% and 35.8\% respectively; Fig 3A; Table 1). These frequencies corresponded to the Ig $\lambda$ expression observed by flow cytometry. Noteworthy, 5 citrullinated-antigen binding cells, of which 3 had the IgG isotype, contained productive sequences for both Igא and Ig $\lambda$ ( $2.7 \%$ and $2.0 \%$ respectively), whereas no double LC sequences were observed for TT-specific cells in either dataset.

To identify clonal expansion, sequences were analyzed for their V-gene, J-gene and the CDR3 region in amino acids (AA). Cells containing an identical V-gene, J-gene and CDR3 (AA) were defined as one clone. This resulted in $168 \mathrm{ACPA}$ clones and 49 TT clones when analyzing the $\mathrm{Ig}_{\text {all }}$ dataset and in $140 \mathrm{ACPA}$ clones and $43 \mathrm{TT}$ clones when analyzing the IgG subset (Fig 3B; Table 1). A trend towards a higher frequency of Ig $\lambda$ in ACPA clones (45.8\% and $47.1 \%$ for $\operatorname{Ig}_{\text {all }}$ and $\operatorname{IgG}$, respectively) compared to TT clones (30.6\% and $32.6 \%$ for $\operatorname{Ig}_{\text {all }}$ and IgG, respectively) was observed when clonal expansions were taken into account. Additionally, the 5 ACPA cells, which contained productive sequences for both IgK and Ig $\lambda$, were also observed in the clone-corrected data (3.1\% and 2.2\%, respectively). To exclude potential bias due to the single cell culture approach, we also assessed pools of ACPA-expressing B cells by next generation sequencing. While no distinction of LCs coupled to IgG, IgA or IgM could be made in this experimental setup, we observed a similar trend for the LC distribution as for the single cell-sorted dataset (37.2\% Ig $\lambda$ versus an expected Ig $\lambda$ frequency of $33 \%$ (Table 1 )).

Altogether, the sequencing analyses demonstrated that the BCR of citrullinated antigenbinding B cells was more frequently composed of a Ig $\lambda$ than a Igא LC compared to BCRs derived from TT-control cells. Furthermore, the results showed that this increase in Ig $\lambda$ was not related to clonal expansion. To determine if specific Igא variable region (IGKV) genes or Ig $\lambda$ variable region (IGLV) genes were common in citrullinated antigen-binding B-cell clones across sequencing methods, we assessed V-region frequencies in Igall single cell-sorted LC clones and compared these to V-region frequencies in $\mathrm{Ig}_{\text {all }}$ pool-sorted LC clones. A similar Vgene pattern was observed for both Igא and Ig $\lambda$ sequences across the different methods (Fig 3C). Intruigingly, IGKV4-1 was predominantly found in both single cell-sorted LC clones (31\%) and pool-sorted LC clones (50\%). Similarly, IGKV1-39, IGKV1-33, IGKV3-15 and IGKV3-20 were substantially represented in both ACPA datasets. Although frequencies of some IGLV-genes were different between the datasets (e.g. IGLV6-57, IGLV3-10 and IGLV2- 
A

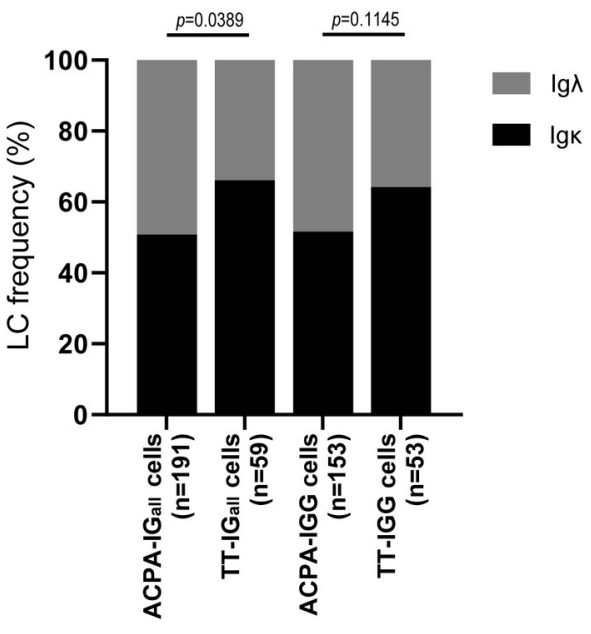

B

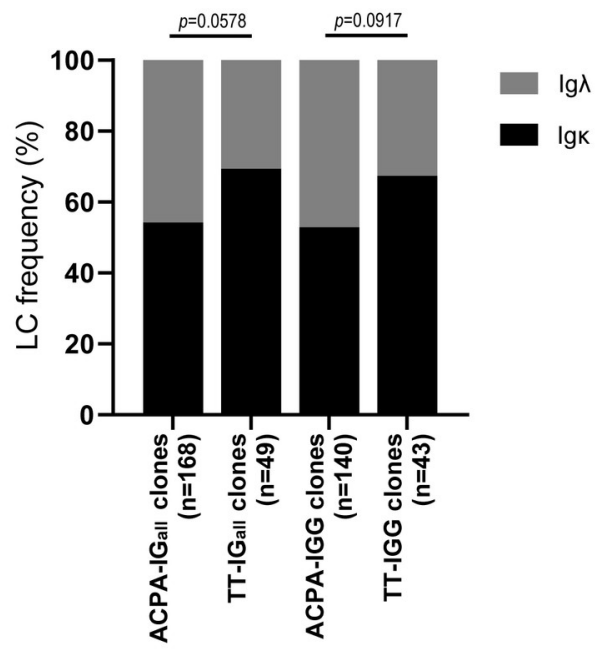

C

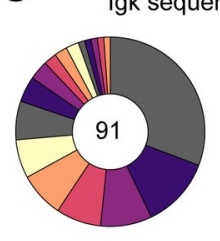

single cell-sorted ACPA-IGall clones

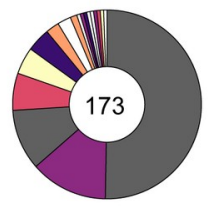

pool-sorted ACPA-IGall clones
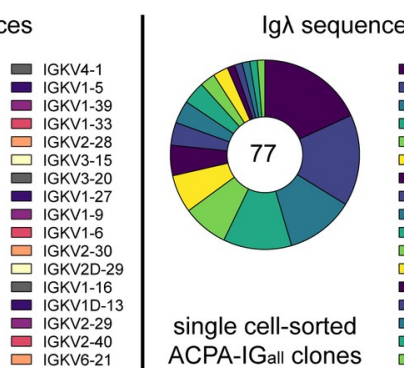

ACPA-IGall clones

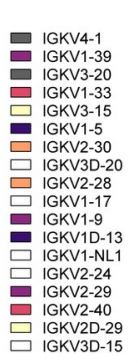

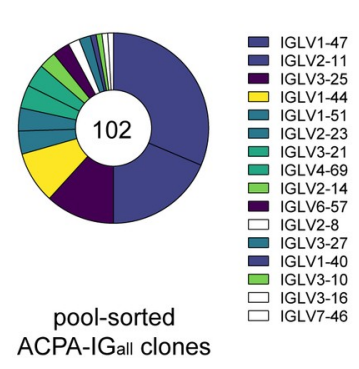

D

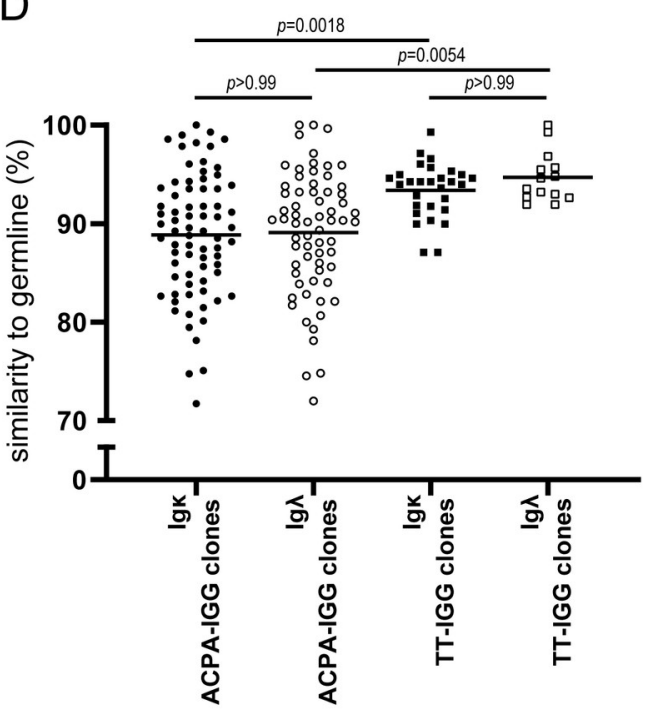

Fig 3. Igא and Ig $\lambda$ frequency and characteristics in BCR sequences of citrullinated antigen- and TT-binding $B$ cells. $\mathrm{CD} 19^{+} \mathrm{CD} 20^{+}$citrullinated antigen-binding B cells (derived from 19 patients) or TT-binding B cells (derived from 4 out of 19 patients) were single cell FACS-sorted and cultured for 10-13 days. Single cell-derived Igall and IgG sequences were analyzed for Igא and Ig $\lambda$ frequency based on sequences from A) all single cells and B) individual clones (defined as identical V-gene+J-gene +CDR3(AA)) to exclude bias due to clonal expansion. Data were statistically analyzed with Chi square test and Holm-Bonferroni correction for multiple comparisons. C) V-gene repertoire of single cell- and pool-sorted ACPA-Igא clones (left panels) and ACPA-Ig $\lambda$ clones (right panels). V-genes, which were not present in single cell-sorted ACPA-LC clones, were colored white in the pie charts of pool-sorted ACPA-LC clones. D) Mutation rate of Igא and Ig $\lambda$ sequences in citrullinated antigen- and TT-binding B cells. Data was statistically analyzed with One-way ANOVA and Holm-Bonferroni correction for multiple comparisons.

https://doi.org/10.1371/journal.pone.0247847.g003

11), 13 of 17 IGLV-genes were discovered in both datasets. In contrast to the predominantly expressed IGKV4-1 in ACPA-IgK clones, a dominant IGLV-gene could not be observed in ACPA-Ig $\lambda$ clones. However, IGLV1-47 was frequently found among IGLV-genes in single cell-sorted ACPA-Ig $\lambda$ clones (16\%) and in pool-sorted ACPA-Ig $\lambda$ clones (31\%). Altogether, these data indicate a diverse $\mathrm{LC}$ repertoire in BCRs of citrullinated antigen-binding $\mathrm{B}$ cells with a frequent presence of IGKV4-1 in ACPA-Igk clones. 
Finally, we determined the mutation rate in LC sequences of citrullinated antigen- and TTbinding B cell clones. We exclusively analyzed LCs obtained with single cell sequencing that were paired with IgG-isotype HCs. No significant differences were observed between Igא and Ig $\lambda$ mutation rates within either antigen-specific BCR repertoire. Nevertheless, both Igא and Ig $\lambda$ sequences derived from ACPA-expressing B cells contained more mutations (were less similar to germline) than their TT-specific counterparts (Fig 3D).

To summarize, the higher lambda LC frequency observed in serum and on the cellular level was supported by an increase in lambda LCs in sequences corrected for clonal expansion. Pool-sorted ACPA B-cell clones showed a similar trend towards an increased Ig $\lambda$ frequency as clones obtained with single cell cultures, excluding survival bias within the cell cultures. Lastly, our sequence data showed diverse IgK and Ig $\lambda$ repertoires, with a high frequency of IGKV4-1 in ACPA-Igא clones, and no significant difference in the mutation rate of Igא and Ig $\lambda$ in ACPA-LC clones.

\section{Discussion}

To prevent autoimmunity, the rearrangement of antibody light chains is an important mechanism by which B cells can modify autoreactive B-cell receptors during different stages of B-cell development and maturation. Autoreactive B cells emerge as drivers of autoimmune diseases despite such control mechanisms for reasons that are incompletely understood. Notably, the composition and sequence characteristics of antibody LCs can provide insights in the developmental steps and selection processes that autoreactive $B$ cells have been exposed to. Here, we investigated the LC characteristics of ACPA-expressing B cells and in the secreted ACPA-IgG repertoire. We report that serum ACPA-IgG contain a higher frequency of lambda LCs compared to paired control IgG. A similar trend was observed in synovial fluid of RA patients and the same skewed LC pattern was observed on the cellular and molecular level in citrullinated antigen-binding B cells. Together, these data indicate that ACPA-expressing B cells develop under conditions that favor LC rearrangements leading to the expression of genes of the lambda locus.

The $\kappa / \lambda$ LC ratio of the antibody repertoire in healthy individuals averages $67 \%$-to-33\%, which is in line with the results of control IgG in our data $[19,20]$. A skewing in LCs has been described for several diseases. A higher $\kappa / \lambda \mathrm{LC}$ ratio, i.e. a predominance of Igк, has been observed for anti-granulocyte colony-stimulating factor antibodies [35], non-specific IgG antibodies in mixed connective tissue disease [36] and for $\mathrm{CD} 10^{+} \mathrm{B}$ cells in Hashimoto thyroiditis (HT) [37]. In contrast, a skewing towards Ig $\lambda$ has been described for anti-neutrophil antibodies [38], thyroid-stimulating autoantibodies [39], anti-lamin B antibodies [40] and circulating immune complexes in juvenile idiopathic arthritis (JIA) [41]. As the composition of the autoantibody repertoire in serum likely reflects the composition of the autoantibody secreting Bcell compartment (i.e. plasmablasts/plasma cells) [4,42], the predominance of $\operatorname{Ig} \lambda$ in the secreted ACPA-IgG repertoire could be explained by selective survival and/or expansion of Ig $\lambda$-antibody producing B-cell clones. Alternatively, it could be inherent to the citrullinated antigen-binding B-cell repertoire, irrespective of the maturation stage of the B-cell response. Our flow cytometry results support the latter, as the increased Ig $\lambda$ frequency was also detectable in citrullinated antigen-binding B cells (predominantly memory B cells). To further exclude the preferential expansion of Ig $\lambda$-expressing B-cell clones, we analyzed BCR sequences derived from single cell-cultured ACPA-expressing B cells. These sequences showed a similar trend towards increased Ig $\lambda$ frequency, complementary to our observations by flow cytometry and the analysis of secreted ACPA-IgG. When corrected for clonality, based on the definition that cells with an identical V-gene, J-gene and CDR3 AA sequence belong to the same clone, 
the skewing towards a higher Ig $\lambda$ frequency remained. Importantly, we did not observe a similar phenomenon for TT-specific B cells in the same patients. Finally, to exclude bias due to differential B-cell survival in vitro, we performed next generation sequencing of pool-sorted ACPA-expressing B cells, which showed a similar trend. Together, these results support the notion that the increased Ig $\lambda$ frequency observed for ACPA is not due to clonal expansion of individual B cells, but rather that citrullinated antigen-binding B cells express Ig $\lambda$ more frequently than their non-autoreactive counterparts.

To our knowledge, this is the first in-depth analysis of the LC repertoire of ACPA-expressing B cells in RA. Previously reported studies focussed on either small numbers of monoclonal antibodies and their functional features [43-45], or did not report sufficient data on LC frequency to perform comparative analyses [46].

Predominance of Ig $\lambda$ in the ACPA BCR repertoire suggests that certain IGLV-genes or Vgene characteristics could facilitate the recognition of citrullinated antigens. Therefore, we analyzed V-gene frequencies in ACPA-Igא and -Ig $\lambda$ clones. IGKV- and IGLV-gene patterns were similar for both our sequencing approaches and displayed a diverse repertoire. Intriguingly, IGKV4-1 was observed in both ACPA-Igא datasets as a dominant IGKV-gene, whereas this $\mathrm{V}$-gene is not as commonly present in non-specific Igא repertoires [47,48]. Notably, the high frequency of IGKV4-1 in ACPA-Igk clones observed by us is supported by the high prevalence of IGKV4-1 in sequences derived from citrullinated fillagrin (CFC1)/ $\alpha$-enolase (CEP1)-binding B cells described by Titcombe et al. [46]. In the Ig $\lambda$ repertoire we observed a higher frequency of IGLV1-47 in both single cell- and pool-sorted ACPA-Ig $\lambda$ datasets (16\% and 31\%, respectively), compared to IGLV1-47 expression reported for B cells derived from human cord blood (6\%) and normal controls ( 10\%) [49,50]. Despite these enhanced frequencies for certain $\mathrm{V}$-genes, our findings do not show a highly restricted LC repertoire as observed in mice studies on certain antigen-specific B-cell responses (e.g. anti-p-azophenylarsonate (Ars) antibodies $[15,16]$ and anti-Haemophilus influenzae type $b$ capsular polysaccharide (Hib PS) antibodies $[17,18])$. In addition, no specific LCs have been associated with multiple autoimmune diseases in human, in contrast to selected heavy chain V-genes (e.g. IGHV4-34, previously called IGHV4-21, and IGHV3-23 [51-58]). More structural analyses would be needed to study the importance of LCs with IGKV4-1 in the recognition of citrullinated antigens and its role in a developing ACPA response.

Our data do not allow us to specifically determine whether the increased Ig $\lambda$ frequency in ACPA-expressing B cells is due to enhanced receptor editing in the bone marrow, receptor revision in the periphery or another unknown process. Considering receptor revision in the periphery, a relatively 'late' event in B-cell maturation, rearrangement of the LC would presumably be preceeded by various passages of ACPA-expressing B cells through GCs. In this case, it would be conceivable that kappa LCs show more extensive somatic hypermutation than lambda LCs. Interestingly, our data showed no difference in the somatic hypermutation rate between Igא and Ig $\lambda$ sequences, suggesting that the increased Ig $\lambda$ frequency is not the result of receptor revision in the periphery but occurs earlier in B-cell development.

To understand when this divergent LC composition is generated, the $\kappa / \lambda$ ratio of the LC repertoire of ACPA IgM-expressing B-cell clones should be analyzed in comparison to the LC repertoire of ACPA-IgG B-cell clones. However, feasibility is limited given the very low frequency of such cells in the periphery and the limitations associated with obtaining bone marrow-derived ACPA-expressing B cells. Nonetheless, based on our data, we would expect the IgM- or naïve compartment to show a similar skewing of the $\mathrm{LC}$ repertoire. This would be in line with the idea that the shift towards Ig $\lambda$ occurs early in the B-cell development.

Finally, our flow cytometry results indicate that $5 \%$ of citrullinated antigen-binding B cells contain both Igא and Ig $\lambda$ compared to $0.5-1.5 \%$ of dual LC-expressing clones in total 
$\mathrm{CD} 19^{+} \mathrm{CD} 20^{+}$and TT-specific $\mathrm{B}$ cells in RA patients, and compared to the range of $0.2-0.5 \%$ reported for healthy individuals $[59,60]$. Dual LC expression has been described abundantly in SLE. In mouse studies, B cells with dual $\mathrm{IgK}^{+} / \mathrm{IgK}^{+} \mathrm{LC}$ expression were more frequently antiDNA reactive. Additionally, studies in SLE patients reported frequencies of dual $\operatorname{IgK}{ }^{+} / \operatorname{Ig} \lambda^{+}$ expression of up to $28 \%$ [61,62]. Allelic inclusion, the expression of BCRs with two different LCs, has been suggested as a way by which autoreactive B cells escape negative selection by "diluting" their autoreactive BCR with a second, non-autoreactive BCR to decrease signaling by autoantigens and increase the threshold for apoptosis $[63,64]$. To what extent this mechanism could also be relevant for ACPA-expressing B-cell maturation remains unknown.

In conclusion, we provide evidence for a skewing towards lambda LCs in secreted ACPA-IgG isolated from serum and synovial fluid, in surface expression on citrullinated antigen-binding $B$ cells and in the BCR repertoire of these cells. Our data indicate that citrullinated antigen-binding $B$ cells are under selective pressure, which may lead to LC rearrangements to avoid clonal deletion. Whether defective negative selection mechanisms are at play or whether citrullinated antigen-binding B cells receive additional survival signals that inhibit this deletion are interesting aspects of further investigations.

\section{Supporting information}

S1 Fig. In-depth gating strategy for determination of Igא and Ig $\lambda$ expression in CD19 +CD20+, TT-binding and citrullinated antigen-binding B cells. All subsets were gated on lymphocytes, single cells and CD19 (while negative for dead cell stain kit, CD3 and CD14). Subsequently, B cells were gated on $\mathrm{CD} 19^{+} \mathrm{CD} 20^{+}$for total B cells control and antigen-specific B-cell subsets. B cells were defined as tetanus toxoid (TT)-binding B cells when $\mathrm{CD} 19^{+} \mathrm{CD} 20^{+}$ cells stained double positive for TT-APC and TT-PE. B cells were defined as citrullinated antigen-binding $\mathrm{B}$ cells when $\mathrm{CD} 19^{+} \mathrm{CD} 20^{+}$cells stained double positive for $\mathrm{CCP} 2-\mathrm{APC}$ and CCP2-BV605 while negative for CArgP2 control.

(DOCX)

\section{S1 Table. Overview of primer sequences.} (DOCX)

S2 Table. LC data derived from citrullinated antigen- and tetanus-binding B cells. (PDF)

\section{Acknowledgments}

We thank Jan Wouter Drijfhout (LUMC, Leiden, The Netherlands) for providing the CCP2 and arginine control peptides. We thank Maikel van Oosterhout for providing synovial fluid samples. We thank the Flow cytometry Core Facility of the LUMC for technical support and the Leiden Genome Technology Center (LGTC) for their expertise and processing of sequencing samples.

\section{Author Contributions}

Conceptualization: Linda M. Slot, Rochelle D. Vergroesen, Priscilla F. Kerkman, Tom W. J. Huizinga, René E. M. Toes, Hans U. Scherer.

Formal analysis: Linda M. Slot, Rochelle D. Vergroesen, Sanne Reijm, Hugo J. van Dooren.

Funding acquisition: René E. M. Toes, Hans U. Scherer. 
Investigation: Linda M. Slot, Rochelle D. Vergroesen, Priscilla F. Kerkman, Ellen Staudinger, Sanne Reijm, Hugo J. van Dooren, Ellen I. H. van der Voort.

Methodology: Linda M. Slot, Rochelle D. Vergroesen, Priscilla F. Kerkman.

Project administration: Linda M. Slot, Rochelle D. Vergroesen, Priscilla F. Kerkman, Ellen Staudinger, Sanne Reijm, Hugo J. van Dooren, Ellen I. H. van der Voort, Hans U. Scherer.

Supervision: Linda M. Slot, Ellen I. H. van der Voort, Tom W. J. Huizinga, René E. M. Toes, Hans U. Scherer.

Validation: Linda M. Slot, Rochelle D. Vergroesen.

Visualization: Linda M. Slot, Rochelle D. Vergroesen.

Writing - original draft: Linda M. Slot, Rochelle D. Vergroesen, Priscilla F. Kerkman, René E. M. Toes, Hans U. Scherer.

Writing - review \& editing: Linda M. Slot, Rochelle D. Vergroesen, Ellen Staudinger, Sanne Reijm, Hugo J. van Dooren, Ellen I. H. van der Voort, Tom W. J. Huizinga, René E. M. Toes, Hans U. Scherer.

\section{References}

1. Scherer HU, Huizinga TWJ, Kronke G, Schett G, Toes REM. The B cell response to citrullinated antigens in the development of rheumatoid arthritis. Nat Rev Rheumatol. 2018; 14(3):157-69. https://doi. org/10.1038/nrrheum.2018.10 PMID: 29416134

2. Willemze A, Trouw LA, Toes RE, Huizinga TW. The influence of ACPA status and characteristics on the course of RA. Nat Rev Rheumatol. 2012; 8(3):144-52. https://doi.org/10.1038/nrrheum.2011.204 PMID: 22293763

3. Vincent C, Nogueira L, Clavel C, Sebbag M, Serre G. Autoantibodies to citrullinated proteins: ACPA. Autoimmunity. 2005; 38(1):17-24. https://doi.org/10.1080/08916930400022582 PMID: 15804701

4. Kerkman PF, Fabre E, van der Voort El, Zaldumbide A, Rombouts $Y$, Rispens $T$, et al. Identification and characterisation of citrullinated antigen-specific $B$ cells in peripheral blood of patients with rheumatoid arthritis. Ann Rheum Dis. 2016; 75(6):1170-6. https://doi.org/10.1136/annrheumdis-2014-207182 PMID: 26034045

5. Suwannalai $P$, Trouw $L A$, Toes RE, Huizinga TW. Anti-citrullinated protein antibodies (ACPA) in early rheumatoid arthritis. Mod Rheumatol. 2012; 22(1):15-20. https://doi.org/10.1007/s10165-011-0486-8 PMID: 21732051

6. Trouw LA, Huizinga TW, Toes RE. Autoimmunity in rheumatoid arthritis: different antigens-common principles. Ann Rheum Dis. 2013; 72(2):2012-202349. https://doi.org/10.1136/annrheumdis-2012202349 PMID: 23253931

7. Suwannalai P, Scherer HU, van der Woude D, loan-Facsinay A, Jol-van der Zijde CM, van Tol MJ, et al. Anti-citrullinated protein antibodies have a low avidity compared with antibodies against recall antigens. Ann Rheum Dis. 2011; 70(2):373-9. https://doi.org/10.1136/ard.2010.135509 PMID: 21068094

8. Vergroesen RD, Slot LM, Hafkenscheid L, Koning MT, van der Voort EIH, Grooff CA, et al. B-cell receptor sequencing of anti-citrullinated protein antibody (ACPA) IgG-expressing B cells indicates a selective advantage for the introduction of $\mathrm{N}$-glycosylation sites during somatic hypermutation. Ann Rheum Dis. 2018; 77(6):956-8. https://doi.org/10.1136/annrheumdis-2017-212052 PMID: 28835463

9. Rombouts $\mathrm{Y}$, Willemze A, van Beers JJ, Shi J, Kerkman PF, van Toorn L, et al. Extensive glycosylation of ACPA-IgG variable domains modulates binding to citrullinated antigens in rheumatoid arthritis. Ann Rheum Dis. 2016; 75(3):578-85. https://doi.org/10.1136/annrheumdis-2014-206598 PMID: 25587188

10. Hafkenscheid L, Bondt A, Scherer HU, Huizinga TW, Wuhrer M, Toes RE, et al. Structural Analysis of Variable Domain Glycosylation of Anti-Citrullinated Protein Antibodies in Rheumatoid Arthritis Reveals the Presence of Highly Sialylated Glycans. Mol Cell Proteomics. 2017; 16(2):278-87. https://doi.org/10. 1074/mcp.M116.062919 PMID: 27956708

11. Kissel T, Reijm S, Slot LM, Cavallari M, Wortel CM, Vergroesen RD, et al. Antibodies and B cells recognising citrullinated proteins display a broad cross-reactivity towards other post-translational modifications. Ann Rheum Dis. 2020; 79(4):472-80. https://doi.org/10.1136/annrheumdis-2019-216499 PMID: 32041746 
12. Goodnow CC, Vinuesa CG, Randall KL, Mackay F, Brink R. Control systems and decision making for antibody production. Nat Immunol. 2010; 11(8):681-8. https://doi.org/10.1038/ni.1900 PMID: 20644574

13. Mehr R, Shannon M, Litwin S. Models for antigen receptor gene rearrangement. I. Biased receptor editing in B cells: implications for allelic exclusion. J Immunol. 1999; 163(4):1793-8. PMID: 10438911

14. van der Burg M, Tumkaya T, Boerma M, de Bruin-Versteeg S, Langerak AW, van Dongen JJ. Ordered recombination of immunoglobulin light chain genes occurs at the IGK locus but seems less strict at the IGL locus. Blood. 2001; 97(4):1001-8. https://doi.org/10.1182/blood.v97.4.1001 PMID: 11159529

15. Wysocki LJ, Gridley T, Huang S, Grandea AG, 3rd, Gefter ML. Single germline VH and V kappa genes encode predominating antibody variable regions elicited in strain $A$ mice by immunization with $p$-azophenylarsonate. J Exp Med. 1987; 166(1):1-11. https://doi.org/10.1084/jem.166.1.1 PMID: 3036994

16. Sanz I, Capra JD. V kappa and J kappa gene segments of A/J Ars-A antibodies: somatic recombination generates the essential arginine at the junction of the variable and joining regions. Proc Natl Acad Sci U S A. 1987; 84(4):1085-9. https://doi.org/10.1073/pnas.84.4.1085 PMID: 3103124

17. Adderson EE, Shackelford PG, Insel RA, Quinn A, Wilson PM, Carroll WL. Immunoglobulin light chain variable region gene sequences for human antibodies to Haemophilus influenzae type $b$ capsular polysaccharide are dominated by a limited number of $\mathrm{V}$ kappa and $\mathrm{V}$ lambda segments and VJ combinations. J Clin Invest. 1992; 89(3):729-38. https://doi.org/10.1172/JCl115649 PMID: 1541667

18. Adderson EE, Shackelford PG, Quinn A, Wilson PM, Cunningham MW, Insel RA, et al. Restricted immunoglobulin VH usage and VDJ combinations in the human response to Haemophilus influenzae type b capsular polysaccharide. Nucleotide sequences of monospecific anti-Haemophilus antibodies and polyspecific antibodies cross-reacting with self antigens. J Clin Invest. 1993; 91(6):2734-43. https://doi.org/10.1172/JCl116514 PMID: 8514881

19. Janeway's Immunobiology. Ninth Edition by Kenneth Murphy, Casey Weaver, Allan Mowat, Leslie Berg, David Chaplin, Charles A. Janeway, Paul Travers, and Mark Walport. The Quarterly Review of Biology. 2018;93(1):59-.

20. Lam CW, Chui SH, Leung NW, Li EK, Lai KN. Light chain ratios of serum immunoglobulins in disease. Clin Biochem. 1991; 24(3):283-7. https://doi.org/10.1016/0009-9120(91)80021-t PMID: 1908361

21. Kim HJ, Krenn V, Steinhauser G, Berek C. Plasma cell development in synovial germinal centers in patients with rheumatoid and reactive arthritis. J Immunol. 1999; 162(5):3053-62. PMID: 10072558

22. Rochas $C$, Hillion $S$, Youinou $P$, Jamin $C$, Devauchelle-Pensec V. RAG-mediated secondary rearrangements of B-cell antigen receptors in rheumatoid synovial tissue. Autoimmun Rev. 2007; 7(2):155-9. https://doi.org/10.1016/j.autrev.2007.02.011 PMID: 18035327

23. Zhang Z, Wu X, Limbaugh BH, Bridges SL Jr., Expression of recombination-activating genes and terminal deoxynucleotidyl transferase and secondary rearrangement of immunoglobulin kappa light chains in rheumatoid arthritis synovial tissue. Arthritis Rheum. 2001; 44(10):2275-84. https://doi.org/10.1002/ 1529-0131(200110)44:10<2275::aid-art390>3.0.co;2-k PMID: 11665968

24. Nagafuchi H, Yoshikawa H, Takeba $Y$, Nara K, Miura K, Kurokawa MS, et al. Recombination activating genes (RAG) induce secondary Ig gene rearrangement in and subsequent apoptosis of human peripheral blood circulating B lymphocytes. Clin Exp Immunol. 2004; 136(1):76-84. https://doi.org/10.1111/j. 1365-2249.2004.02423.x PMID: 15030517

25. Sozzi E, Amato T, Sahota SS, Nuti S, Raspadori D, Sicuranza A, et al. Lack of allelic exclusion by secondary rearrangements of tumour B-cell receptor light chains in hairy cell leukaemia. Hematol Oncol. 2011; 29(1):31-7. https://doi.org/10.1002/hon.952 PMID: 20658474

26. Han S, Dillon SR, Zheng B, Shimoda M, Schlissel MS, Kelsoe G. V(D)J recombinase activity in a subset of germinal center B lymphocytes. Science. 1997; 278(5336):301-5. https://doi.org/10.1126/science. 278.5336.301 PMID: 9323211

27. Diaw L, Siwarski D, DuBois W, Jones G, Huppi K. Double producers of kappa and lambda define a subset of B cells in mouse plasmacytomas. Mol Immunol. 2000; 37(12-13):775-81. https://doi.org/10. 1016/s0161-5890(00)00100-0 PMID: 11275262

28. Maes J, Caspi Y, Rougeon F, Haimovich J, Goodhardt M. Secondary V(D)J rearrangements and B cell receptor-mediated down-regulation of recombination activating gene-2 expression in a murine $\mathrm{B}$ cell line. J Immunol. 2000; 165(2):703-9. https://doi.org/10.4049/jimmunol.165.2.703 PMID: 10878342

29. Aletaha D, Neogi T, Silman AJ, Funovits J, Felson DT, Bingham CO, 3rd, et al. 2010 Rheumatoid arthritis classification criteria: an American College of Rheumatology/European League Against Rheumatism collaborative initiative. Arthritis Rheum. 2010; 62(9):2569-81. https://doi.org/10.1002/art.27584 PMID: 20872595

30. Habets KL, Trouw LA, Levarht EW, Korporaal SJ, Habets PA, de Groot P, et al. Anti-citrullinated protein antibodies contribute to platelet activation in rheumatoid arthritis. Arthritis Res Ther. 2015; 17 (209):015-0665. https://doi.org/10.1186/s13075-015-0665-7 PMID: 26268317 
31. Lighaam LC, Vermeulen E, Bleker T, Meijlink KJ, Aalberse RC, Barnes E, et al. Phenotypic differences between IgG4+ and IgG1+B cells point to distinct regulation of the IgG4 response. J Allergy Clin Immunol. 2014; 133(1):267-70. https://doi.org/10.1016/j.jaci.2013.07.044 PMID: 24074895

32. Koning MT, Kielbasa SM, Boersma V, Buermans HPJ, van der Zeeuw SAJ, van Bergen CAM, et al. ARTISAN PCR: rapid identification of full-length immunoglobulin rearrangements without primer binding bias. Br J Haematol. 2017; 178(6):983-6. https://doi.org/10.1111/bjh.14180 PMID: 27301611

33. Giudicelli V, Brochet $X$, Lefranc MP. IMGT/V-QUEST: IMGT standardized analysis of the immunoglobulin (IG) and T cell receptor (TR) nucleotide sequences. Cold Spring Harb Protoc. 2011; 1(6):695-715.

34. IJspeert H, van Schouwenburg PA, van Zessen D, Pico-Knijnenburg I, Stubbs AP, van der Burg M. Antigen Receptor Galaxy: A User-Friendly, Web-Based Tool for Analysis and Visualization of T and B Cell Receptor Repertoire Data. J Immunol 2017. 198(10):4156-65. https://doi.org/10.4049/jimmunol. 1601921 Epub 2017 Apr 17. PMID: 28416602

35. Nei T, Urano S, Itoh Y, Kitamura N, Hashimoto A, Tanaka T, et al. Light chain (kappa/lambda) ratio of GM-CSF autoantibodies is associated with disease severity in autoimmune pulmonary alveolar proteinosis. Clin Immunol. 2013; 149(3):357-64. https://doi.org/10.1016/j.clim.2013.10.002 PMID: 24211842

36. Haraldsson A, Tiddens HA, Fiselier T, Bakkeren JA, Weemaes CM. Altered immunoglobulin concentrations and light chain ratios in juvenile onset mixed connective tissue disease. Clin Rheumatol. 1995; 14 (1):51-4. https://doi.org/10.1007/BF02208084 PMID: 7743744

37. Chen HI, Akpolat I, Mody DR, Lopez-Terrada D, De Leon AP, Luo Y, et al. Restricted kappa/lambda light chain ratio by flow cytometry in germinal center B cells in Hashimoto thyroiditis. Am J Clin Pathol. 2006; 125(1):42-8. PMID: 16482990

38. Shastri KA, O'Connor BM, Logue GL, Shimm DS, Rustagi PK. Light chain composition of serum granulocyte binding immunoglobulins. Am J Hematol. 1991; 37(3):167-72. https://doi.org/10.1002/ajh. 2830370307 PMID: 1907094

39. Knight J, Laing P, Knight A, Adams D, Ling N. Thyroid-stimulating autoantibodies usually contain only lambda-light chains: evidence for the "forbidden clone" theory. J Clin Endocrinol Metab. 1986; 62 (2):342-7. https://doi.org/10.1210/jcem-62-2-342 PMID: 2867105

40. Reeves WH, Ali SA. Preferential use of lambda L chain in lamin B autoantibodies. J Immunol. 1989; 143 (11):3614-8. PMID: 2511246

41. Low JM, Chauhan AK, Moore TL. Abnormal kappa:lambda light chain ratio in circulating immune complexes as a marker for B cell activity in juvenile idiopathic arthritis. Scand J Immunol. 2007; 65(1):7683. https://doi.org/10.1111/j.1365-3083.2006.01859.x PMID: 17212770

42. Kristyanto H, Blomberg NJ, Slot LM, van der Voort EIH, Kerkman PF, Bakker A, et al. Persistently activated, proliferative memory autoreactive $B$ cells promote inflammation in rheumatoid arthritis. Sci Trans Med. 2020; 12(570). https://doi.org/10.1126/scitransImed.aaz5327 PMID: 33208502

43. van de Stadt LA, van Schouwenburg PA, Bryde S, Kruithof S, van Schaardenburg D, Hamann D, et al. Monoclonal anti-citrullinated protein antibodies selected on citrullinated fibrinogen have distinct targets with different cross-reactivity patterns. Rheumatology. 2013; 52(4):631-5. https://doi.org/10.1093/ rheumatology/kes371 PMID: 23264551

44. Raats JM, Wijnen EM, Pruijn GJ, van den Hoogen FH, van Venrooij WJ. Recombinant human monoclonal autoantibodies specific for citrulline-containing peptides from phage display libraries derived from patients with rheumatoid arthritis. J Rheumatol. 2003; 30(8):1696-711. PMID: 12913924

45. Steen J, Forsström B, Sahlström P, Odowd V, Israelsson L, Krishnamurthy A, et al. Recognition of Amino Acid Motifs, Rather Than Specific Proteins, by Human Plasma Cell-Derived Monoclonal Antibodies to Posttranslationally Modified Proteins in Rheumatoid Arthritis. Arthritis Rheumatol. 2019; 71 (2):196-209. https://doi.org/10.1002/art.40699 PMID: 30152202

46. Titcombe PJ, Wigerblad G, Sippl N, Zhang N, Shmagel AK, Sahlström P, et al. Pathogenic CitrullineMultispecific B Cell Receptor Clades in Rheumatoid Arthritis. Arthritis Rheumatol. 2018; 70(12):193345. https://doi.org/10.1002/art.40590 PMID: 29927106

47. Foster SJ, Brezinschek HP, Brezinschek RI, Lipsky PE. Molecular mechanisms and selective influences that shape the kappa gene repertoire of IgM+ B cells. J Clin Invest. 1997; 99(7):1614-27. https:// doi.org/10.1172/JCl119324 PMID: 9120005

48. Stamatopoulos K, Belessi C, Hadzidimitriou A, Smilevska T, Kalagiakou E, Hatzi K, et al. Immunoglobulin light chain repertoire in chronic lymphocytic leukemia. Blood. 2005; 106(10):3575-83. https://doi.org/ 10.1182/blood-2005-04-1511 PMID: 16076869

49. Prabakaran P, Chen W, Singarayan MG, Stewart CC, Streaker E, Feng Y, et al. Expressed antibody repertoires in human cord blood cells: 454 sequencing and IMGT/HighV-QUEST analysis of germline gene usage, junctional diversity, and somatic mutations. Immunogenetics. 2012; 64(5):337-50. https:// doi.org/10.1007/s00251-011-0595-8 PMID: 22200891 
50. Kawajiri-Manako C, Mimura N, Fukuyo M, Namba H, Rahmutulla B, Nagao Y, et al. Clonal immunoglobulin $\lambda$ light-chain gene rearrangements detected by next generation sequencing in POEMS syndrome. Am J Hematol. 2018; 93(9):1161-8. https://doi.org/10.1002/ajh.25213 PMID: 30015379

51. van Vollenhoven RF, Bieber MM, Powell MJ, Gupta PK, Bhat NM, Richards KL, et al. VH4-34 encoded antibodies in systemic lupus erythematosus: a specific diagnostic marker that correlates with clinical disease characteristics. J Rheumatol. 1999; 26(8):1727-33. PMID: 10451069

52. Pascual V, Capra JD. VH4-21, a human VH gene segment overrepresented in the autoimmune repertoire. Arthritis Rheum. 1992; 35(1):11-8. https://doi.org/10.1002/art.1780350103 PMID: 1731808

53. Pugh-Bernard AE, Silverman GJ, Cappione AJ, Villano ME, Ryan DH, Insel RA, et al. Regulation of inherently autoreactive VH4-34 B cells in the maintenance of human B cell tolerance. J Clin Invest. 2001; 108(7):1061-70. https://doi.org/10.1172/JCl12462 PMID: 11581307

54. Mockridge $\mathrm{Cl}$, Chapman $\mathrm{CJ}$, Spellerberg MB, Sheth B, Fleming TP, Isenberg DA, et al. Sequence analysis of V(4-34)-encoded antibodies from single B cells of two patients with systemic lupus erythematosus (SLE). Clin Exp Immunol. 1998; 114(1):129-36. https://doi.org/10.1046/j.1365-2249.1998.00703.x PMID: 9764614

55. Silberstein LE, George A, Durdik JM, Kipps TJ. The V4-34 encoded anti-i autoantibodies recognize a large subset of human and mouse B-cells. Blood Cells Mol Dis. 1996; 22(2):126-38. https://doi.org/10. 1006/bcmd.1996.0020 PMID: 8931953

56. Li Y, Spellerberg MB, Stevenson FK, Capra JD, Potter KN. The I binding specificity of human VH 4-34 (VH 4-21) encoded antibodies is determined by both $\mathrm{VH}$ framework region 1 and complementarity determining region 3. J Mol Biol. 1996; 256(3):577-89. https://doi.org/10.1006/jmbi.1996.0110 PMID: 8604140

57. Snir O, Chen X, Gidoni M, du Pré MF, Zhao Y, Steinsbø Ø, et al. Stereotyped antibody responses target posttranslationally modified gluten in celiac disease. JCI Insight. 2017; 2(17):7. https://doi.org/10.1172/ jci.insight.93961 PMID: 28878138

58. Wang J, Bu D, Zhu X. Immunoglobulin variable region gene analysis to the autoantibody-secreting B cells from tumors in association with paraneoplastic autoimmune multiorgan syndrome. Int J Dermatol. 2007; 46(11):1146-54. https://doi.org/10.1111/j.1365-4632.2007.03267.x PMID: 17988333

59. DeKosky BJ, Kojima T, Rodin A, Charab W, Ippolito GC, Ellington AD, et al. In-depth determination and analysis of the human paired heavy- and light-chain antibody repertoire. Nat Med. 2015; 21(1):86-91. https://doi.org/10.1038/nm.3743 PMID: 25501908

60. Giachino C, Padovan E, Lanzavecchia A. kappa+lambda+ dual receptor B cells are present in the human peripheral repertoire. J Exp Med. 1995; 181(3):1245-50. https://doi.org/10.1084/jem.181.3. 1245 PMID: 7869042

61. Fraser LD, Zhao Y, Lutalo PM, D'Cruz DP, Cason J, Silva JS, et al. Immunoglobulin light chain allelic inclusion in systemic lupus erythematosus. Eur J Immunol. 2015; 45(8):2409-19. https://doi.org/10. 1002/eji.201545599 PMID: 26036683

62. Fournier EM, Velez MG, Leahy K, Swanson CL, Rubtsov AV, Torres RM, et al. Dual-reactive B cells are autoreactive and highly enriched in the plasmablast and memory $B$ cell subsets of autoimmune mice. $J$ Exp Med. 2012; 209(10):1797-812. https://doi.org/10.1084/jem.20120332 PMID: 22927551

63. Pelanda R. Dual immunoglobulin light chain B cells: Trojan horses of autoimmunity? Curr Opin Immunol. 2014; 27:53-9. https://doi.org/10.1016/j.coi.2014.01.012 PMID: 24549093

64. Rezanka LJ, Kenny JJ, Longo DL. 2 BCR or NOT 2 BCR-receptor dilution: a unique mechanism for preventing the development of holes in the protective B cell repertoire. Immunobiology. 2005; 210 (10):769-74. https://doi.org/10.1016/j.imbio.2005.10.008 PMID: 16325496 